\title{
Harvesting Feasibility of Rain Water in Buildings
}

\author{
${ }^{1}$ Parya Najifar and $*^{2}$ Cüneyt Kurtay \\ ${ }^{1,2}$ Department of Architecture, Gazi University, Ankara, Turkey
}

\section{Keyword: \\ Rain water \\ Gray water \\ Green building \\ Water usage}

\begin{abstract}
Nowadays, population is rapidly growing especially in urban areas and sufficient water supply and harvesting has changed to an urgent and important challenge to develop equal access to water and social needs. The main reasons of lack of water concern in most areas of the world are increased population, environmental pollution, costs and uncontrolled consumption of water, climate changes since the water is consumed in the cycle without return and completion although water is a renewable source. Various new technologies are developed to overcome such a problem in alternative sources for water. Rain water is of great importance due to its quality, purity, $\mathrm{PH}$ amount, its content salt and minerals. However, due to lower quality and insufficiency of ground and gray water, rainwater it becomes more important. Present research paper investigates water harvesting feasibility in different countries of the world through considering structures in the underlying study areas. Then an approach was presented as a solution for designers and users with design criteria for the use of rain and gray water in the field of construction. In this approach, the case structure is discussed. Rain waters and gray waters usage sufficiency are discussed in this study according to the sample buildings' position in the world.
\end{abstract}

\section{Corresponding Author:}

Cüneyt Kurtay

Department of Architecture

Gazi University,

Celal Bayar Bulvarı, Maltepe, Ankara 06570, Turkey.

Email: kurtay@gazi.edu.tr

\section{Introduction}

Today, the population increases quite rapidly particularly in urban areas, while the supply of water for meeting the needs of society, as well as ensuring equality water access, is recognized as an emergency and significant challenge.

Due to being consumed before completing its cycle based on the population increase, environmental pollution, unconscious water consumption, changes in the climate conditions, though being a renewable resource, the water shortage is on the agenda of many countries around the world. In order to eliminate this problem, the alternative water resources have started to be searched, and currently, various technologies are being developed in line with this purpose.

The rain water is of high importance with regards to its quality, purity, $\mathrm{pH}$ value, including the salt and minerals it contains. Additionally, there is no problem in the separation of artificial and natural contaminants of the rain water. Having limited underground spring water and grey water, and not meeting the criteria for being recognized as potable water, increases the importance of rain water. It will constitute a guiding data during the design process to be aware of the percentage of the water utilized within the structures in 
proportion to the rain water amount depending on the districts and number of users, and that the rain water can be re-supplied with the utilization of grey water, which is generated by using the rain water [1].

In this study, the calculation methods are specified for the rain water and grey water utilization, after designating the methods for collecting and using the rain water in the structures, as well as re-usage of water in these structures. Applying the theoretical information on the sample structures, the benefits as ensured by these practices for various rain areas in all over the world, are researched.

\section{Global Water Potential}

As one of the problems in the global-scale, the water resources are unevenly distributed in terms of spatio and temporal. While certain areas are gifted with a huge amount of water, others are suffering from water shortage. It is possible for the water shortage to turn into water crisis in certain areas, including the Middle East within the next $20-25$ years. Therefore, this unreplaceable natural resource is generally accepted to be as one of the strategical resources of 21 th century [2].

The allocation of water resources are not evet in the world. The American Continent, North Asia, Australia and Central Europe stand out with regards to the water resources owned, while North Africa, Middle East and Southeast Asia are experiencing water shortage. In Figure 1, it can be seen that the ratio of water resources in proportion to the population in North and South America, Australia and Oceania is higher comparing the distribution ratio of water resources in all over the world [2].

Table 1. Population and water resource ratios of the continents in the world

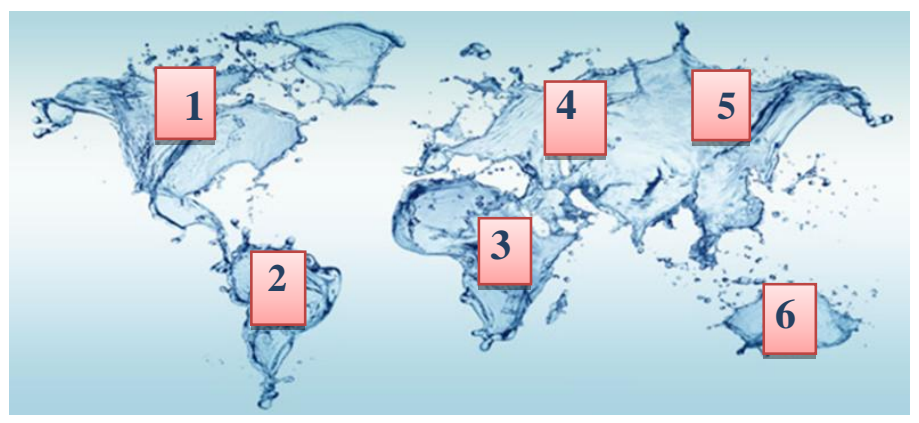

\begin{tabular}{|l|l|l|l|}
\hline & \multicolumn{1}{|c|}{ continents } & $\begin{array}{c}\text { Popul } \\
\text { ation } \\
\%\end{array}$ & $\begin{array}{c}\text { Watersup } \\
\text { ply \% }\end{array}$ \\
\hline 1 & North America & 8 & 15 \\
\hline 2 & South America & 6 & 26 \\
\hline 3 & Africa & 13 & 11 \\
\hline 4 & Europe & 13 & 8 \\
\hline 5 & Asia & 58 & 34 \\
\hline 6 & Australia & 1 & 5 \\
\hline
\end{tabular}

Global Water Consumption; Categorized under 3 groups as agricultural, industrial and domestic, the water consumption amount varies in various regions of the world. The average rates for global consumption is $70 \%$ for agriculture, $22 \%$ for industry and $8 \%$ for domestic usage in accordance with data for the year 2003 by UN World Water Development Report. Today, the potential for accessing sufficient and clean water resources is recognized as an indicator for the development level of the countries. While the global average is $8 \%$ in terms of domestic water usage, this ratio goes up to $11 \%$ in developing countries [2]. In Turkey, the irrigation water utilization rate in agriculture is $75 \%$ (29.6 billion $\mathrm{m} 3$ ), while it is $15 \%$ (6.2 billion $\mathrm{m} 3$ ) for potable and utility water and $11 \%$ (4.3 billion $\mathrm{m} 3$ ) for industrial usage (Table: 2) [3].

The reason for the instability of domestic water usage in different areas is based on the factors that are needed in water demand to differ from each other, along with the possessed clean water resources, as well as the ability to access these resources [4]. 


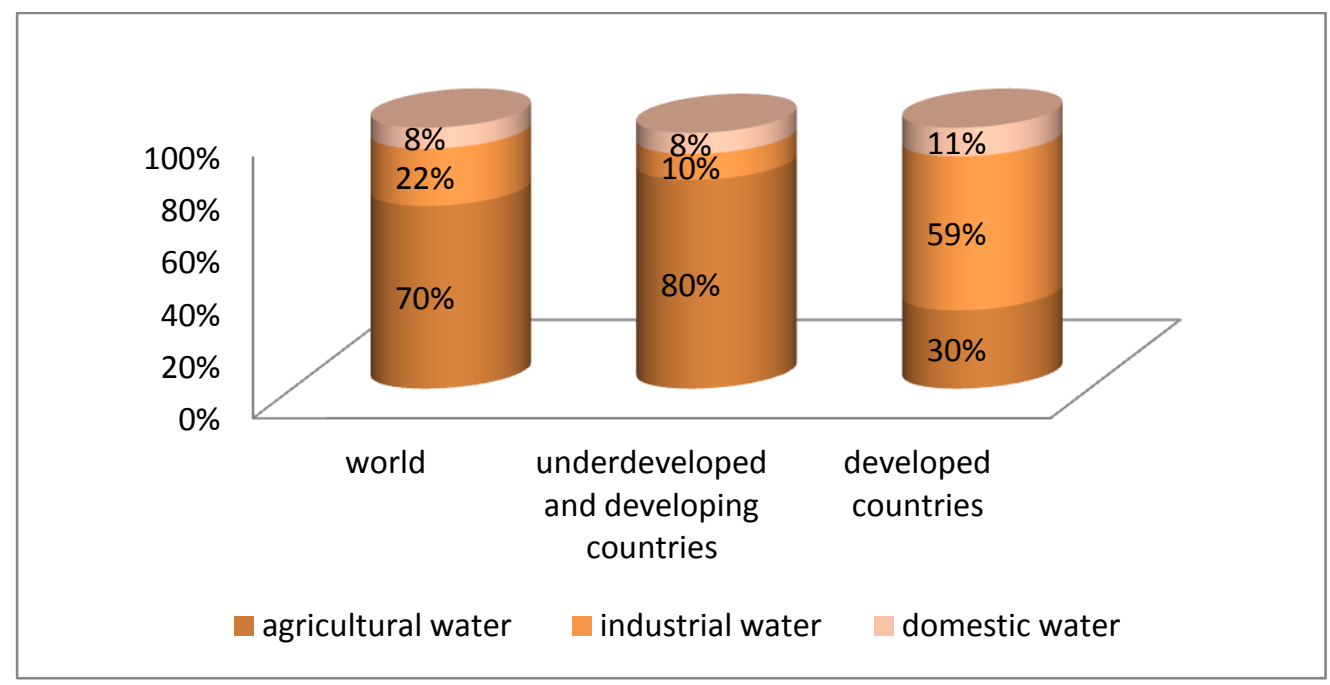

Figure 1. Impact of development level of countries on water consumption (2003) [4]

\section{Rain Water Utilization Methods in Structures}

The rain water utilization in the structure is analyzed under 2 topics

- The rain water is collected via the roof, then directed for the first usage.

- The rain water, which turns into grey water, is subjected to treatment, thus being directed to the second usage.

\subsection{Rain water utilization}

Advantages of rain water utilization:

- The rain water is a needed water resource.

- The physical and chemical characteristics of the rain water is better than the underground waters and surface waters in general.

- A significant reserve can be ensured for emergencies and/or the breakdown of public water supply systems, particularly after natural disasters.

- The construction of rain water collection system in the roof is simple, and these systems can be built in a manner, where almost whole water need is met.

- The concrete reservoirs established as an integral part of the whole building may increase the infrastructure capacity of that building.

- The operational and maintenance costs are lower [5].

Disadvantages of rain water utilization:

- Collecting the rain water depends on the amount of precipitation. Therefore, it is not a reliable water resource in long-term drought periods.

- The possible water leakage of the tanks may cause damage on the foundation of the building.

- The storage tanks may be unsafe for children.

- The water may be contaminated with animal \& plant wastes, where the respective measures are not taken.

- The rain water collection systems may increase the constructional costs.

- Due to not containing the minerals, the rain water may cause innutrition for people [5]. 


\subsection{Definition of the grey water}

The grey water can be defined as the domestic waste waters, except the black water (toilet water); in other words, it is the waste water generated from the shower, bathtub, washbasin, kitchen, as well as the dish washer and washing machine. The black water, on the other hand, is the waste water directed to sewerage system from the toilets, which contains septic waste. In buildings, the grey water can be subjected to water treatment in order to be utilized for garden irrigation, toilet tank or washing machines.

The nitrogen contamination effect within the waste water is the most critical substance, as well as being the hardest to be purified from the potable water. $90 \%$ of the nitrogen within the waste water is generated from the black water, while the grey water contains much lesser amount of nitrogen compared to black water. Hence, the grey water is separated easier compared to the black water, thus being purified within a shorter period of time. Containing much lesser amount of pathogens compared to the black water makes it easier for the grey water to be subjected to water treatment. Additionally, organic substance-rich grey water can be used again in line with certain purposes, by being directed to the water cycle after removing the respective contaminants. The grey water must be purified and disinfected due to containing a microbial load. The chlorine is used for chemical disinfectant. However, ultraviolet \& ozone radiation is suggested with regards to environment and safety. The grey water comprises $50 \%$ to $80 \%$ of the domestic waste water [6].

The black water, on the other hand, can be used in the garden irrigation or toilet tanks after being properly subjected to water treatment.

\subsection{The Health and Safety of Grey Water}

The following must be taken observed in order not to cause the re-utilization of grey water to be contaminated.

- $\quad$ These systems must be established to underground.

- The system must be designed and implemented in a manner preventing the direct contact of grey water with humans and animals.

- It must be designed separately from the clean water system in terms of installation.

- $\quad$ No grey water should be let into the rain water collection system.

- The grey water should not be used for irrigation of vegetables and grass.

- Certain measures like placing the warning labels on the grey water irrigation system must be taken, as well as making predictions as deemed required [7].

\section{Calculation Methods for Rain Water and Grey Water Utilization in The Structures}

For making the calculation of rain water, the global precipitation based climate classification data is required. One of the most critical data from the climate classification is the Köppen Climate Classification method.

\subsection{Köppen Global Climate Classification}

Köppen climate classification was suggested by the German climatolog "WladimirKöppen" in 1900s, and developed considerably by Köppenbetween 1918 - 1936. According to Koppen's classification method, the natural vegetation of an environment is the best analysis tool for describing the climatic characteristics of that region. Therefore, Köppen took the allocation of natural vegetation into consideration while classifying the climatic zones. The boundaries of the climatic zones are settled by calculating the monthly and annual temperature averages of a region, as well as the precipitation amount, with Köppen classification. The climatic zones as designated according to this classification method are as follows [8]. 


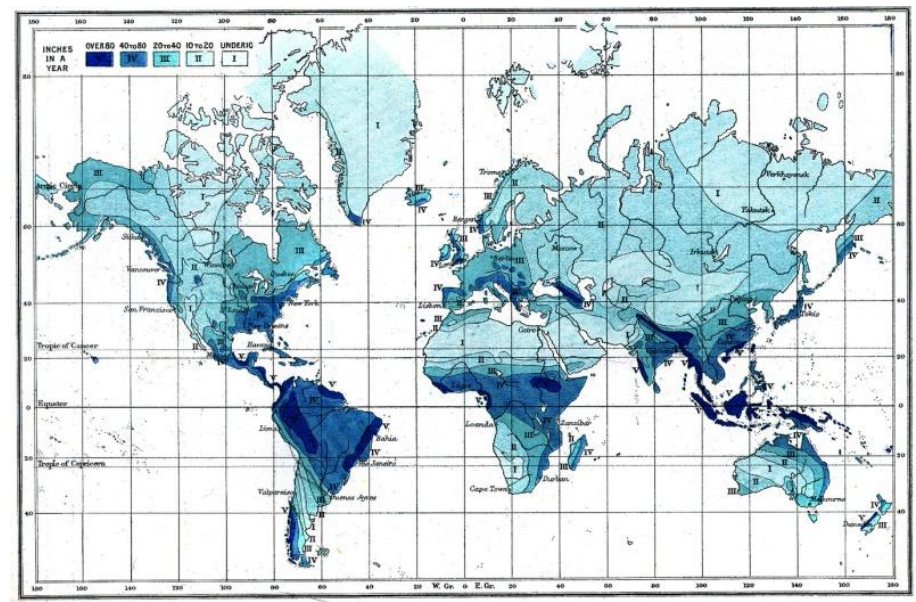

Figure 2: average precipitation $(\mathrm{mm} / \mathrm{y} 1)-2014$ [8]

Table 2. average precipitation $(\mathrm{mm} / \mathrm{y} 1 \mathrm{l})-2014$ [8]

\begin{tabular}{|c|c|c|}
\hline Groups & $\begin{array}{c}\text { average } \\
\text { precipitation } \\
\text { (mm/ yl) }\end{array}$ & Colors \\
\hline $\mathbf{1}$ & $<420$ & \\
\hline $\mathbf{2}$ & $420-870$ & \\
\hline $\mathbf{3}$ & $870-1350$ & \\
\hline $\mathbf{4}$ & $1350-1830$ & \\
\hline $\mathbf{5}$ & $>1830$ & \\
\hline
\end{tabular}

\subsection{Calculation Method for Rain Water Utilization}

Total Amount (liters) = Roof Area $(\mathrm{m} 2) \times$ Precipitation amount $(\mathrm{mm}) \times$ Drainage coefficient

Table 3. Drainage coefficient figures [9]

\begin{tabular}{|l|l|}
\hline \multicolumn{1}{|c|}{ Roof type } & \multicolumn{1}{c|}{ Drainage coefficient } \\
\hline Pitched roof & 0.9 \\
\hline Pitched roof with tiles & 0.8 \\
\hline Flat roof with gravel layer & 0.8 \\
\hline
\end{tabular}

\subsection{Calculation Method for Grey Water Utilization}

The waters that can be used as grey water in buildings are the ones generated from shower, bathroom, washbasin, kitchen and washing machines. The ratio of these waters as proportion to the total water utilization [10].

$\% 40+\% 12+\% 13=\% 65$ 


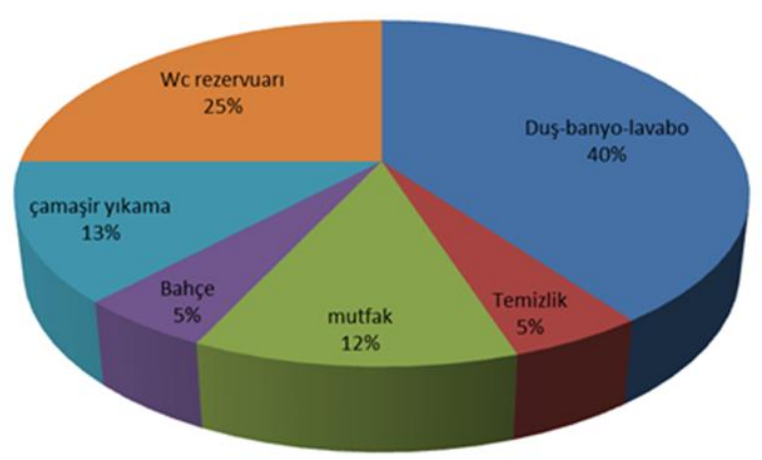

Figure 3. Percentage of used water obtained from activities in residence [10]

\section{Sample Study}

In the study, single and four-storey buildings were designed as per families of 4. Maximum efforts were made to make the single and four-storey building plan similar during the design process, thus trying to keep the differences of distances between the roof areas as low as possible.

The size of the single-storey building, comprising of 3 bedrooms, living room, kitchen and bathroom is $8.00 \times 15.00 \mathrm{~m}$ (roof area: $129.05 \mathrm{~m} 2$ ), while the sizes of four-storey building is cxd $\mathrm{m} .256 .59 \mathrm{~m} 2$. The roof slope was taken as $35 \%$ for both buildings.
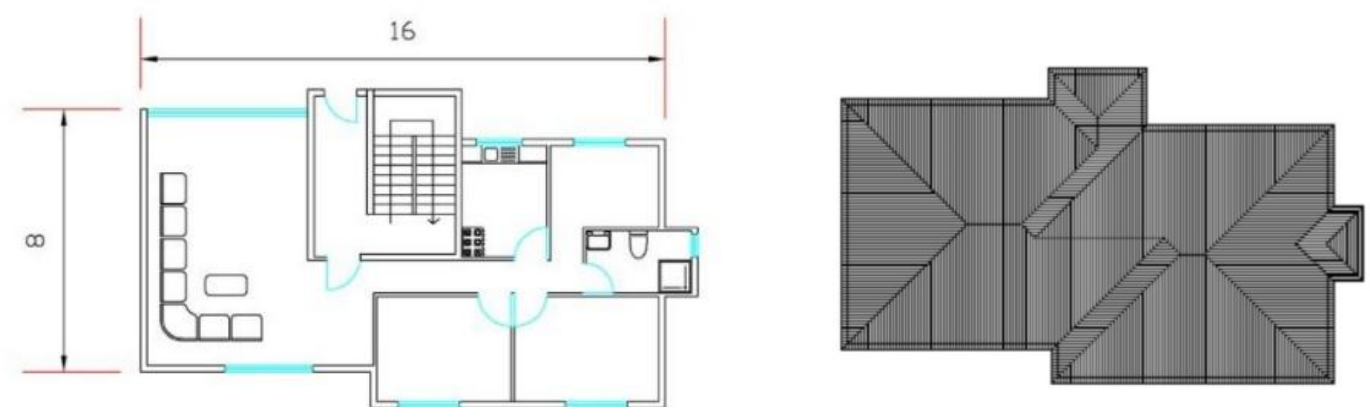

Figure 4. Four storey building's ground and roof plans.
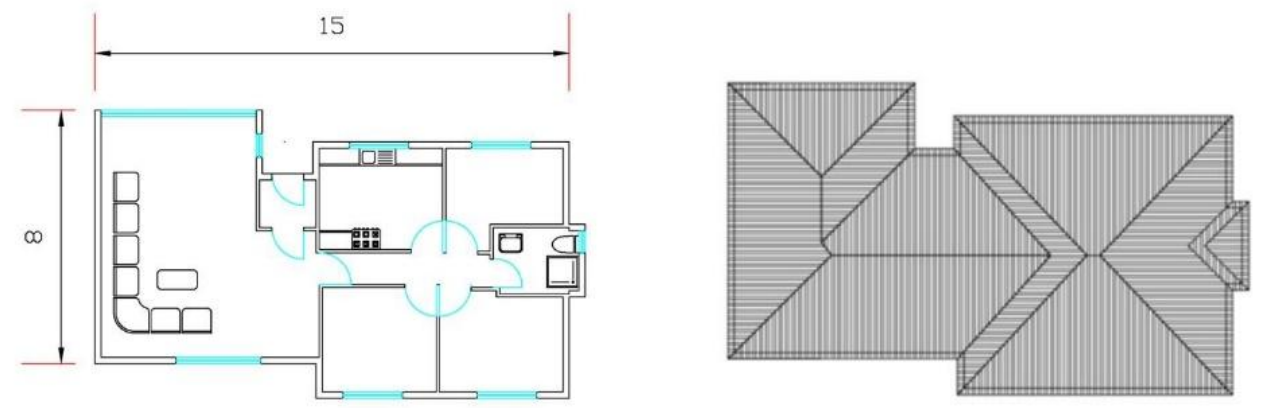

Figure 5. Single building ground and roof plans. 
Table 4. The amount of rain and gray water calculated according to the sample houses.

\begin{tabular}{|c|c|c|c|c|c|}
\hline satisfactoriness & $x$ & $x$ & $x$ & $x$ & $x$ \\
\hline 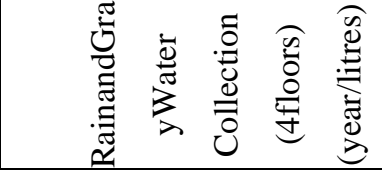 & 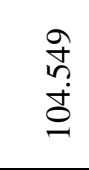 & $\begin{array}{l}\stackrel{O}{\forall} \\
\stackrel{g}{g} \\
\stackrel{g}{I}\end{array}$ & $\begin{array}{l}\tilde{n} \\
\ddot{a} \\
\ddot{n}\end{array}$ & 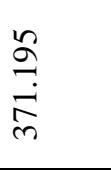 & $\begin{array}{l}\bar{\alpha} \\
\stackrel{\vec{p}}{+}\end{array}$ \\
\hline 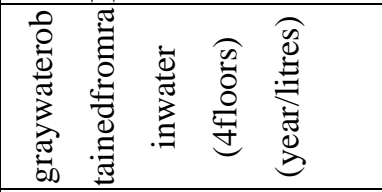 & $\begin{array}{l}\frac{⿱}{2} \\
\frac{\sigma}{\sigma}\end{array}$ & $\begin{array}{l}\infty \\
\infty \\
\infty \\
\infty \\
\infty\end{array}$ & $\begin{array}{l}\text { Oo } \\
0 \\
\text { di } \\
0\end{array}$ & 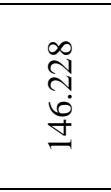 & $\frac{q}{\frac{9}{g}}$ \\
\hline satisfactoriness & $x$ & $>$ & $>$ & $>$ & $>$ \\
\hline 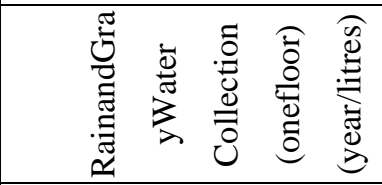 & $\frac{\tilde{n}}{\stackrel{\infty}{\infty}}$ & 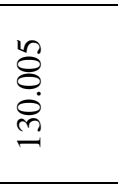 & 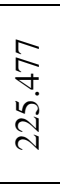 & $\begin{array}{l}\infty \\
\curvearrowright \\
\text { ते } \\
\text { nి }\end{array}$ & $\begin{array}{l}\frac{n}{\hat{n}} \\
\stackrel{n}{n}\end{array}$ \\
\hline 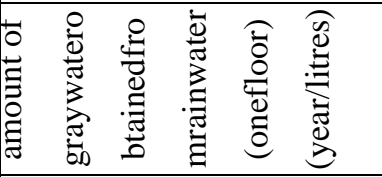 & $\begin{array}{l}\infty \\
\text { \& } \\
\text { in }\end{array}$ & $\frac{\underset{n}{n}}{\stackrel{\Delta}{n}}$ & $\begin{array}{l}\underset{J}{J} \\
\infty \\
\infty \\
\infty\end{array}$ & 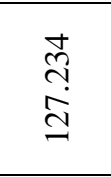 & 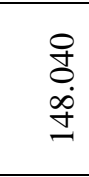 \\
\hline satisfactoriness & $x$ & $x$ & $x$ & $x$ & $x$ \\
\hline 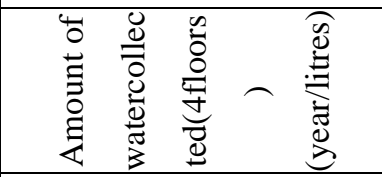 & $\begin{array}{l}\tilde{n} \\
\tilde{n} \\
\stackrel{0}{0}\end{array}$ & 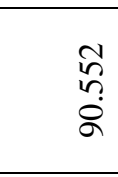 & $\begin{array}{l}\tilde{v} \\
\text { है } \\
\text { nn }\end{array}$ & 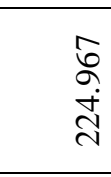 & $\begin{array}{l}\stackrel{+}{2} \\
\frac{\text { Dे }}{2}\end{array}$ \\
\hline 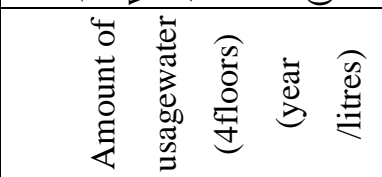 & $\begin{array}{l}8 \\
8 \\
\dot{f} \\
\text { in }\end{array}$ & $\begin{array}{l}8 \\
8 \\
\text { i } \\
\text { in }\end{array}$ & $\begin{array}{l}8 \\
8 \\
\dot{+} \\
\text { in }\end{array}$ & $\begin{array}{l}8 \\
\& \\
\dot{+} \\
\text { in }\end{array}$ & $\begin{array}{l}8 \\
8 \\
\dot{+} \\
\text { in }\end{array}$ \\
\hline satisfactoriness & $x$ & $x$ & $>$ & $>$ & $>$ \\
\hline 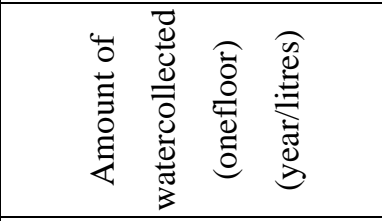 & $\begin{array}{l}\stackrel{J}{\sim} \\
\stackrel{g}{q}\end{array}$ & 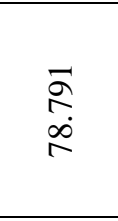 & 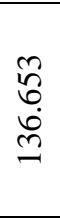 & $\begin{array}{l}0 \\
\stackrel{+}{N} \\
\stackrel{2}{\sigma}\end{array}$ & 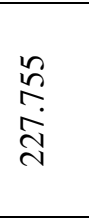 \\
\hline 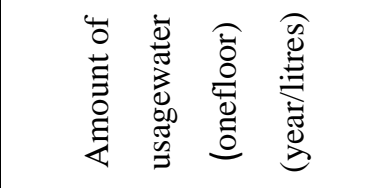 & $\begin{array}{l}8 \\
8 \\
\dot{0} \\
\stackrel{-}{-}\end{array}$ & $\begin{array}{l}8 \\
8 \\
\dot{0} \\
ٍ\end{array}$ & 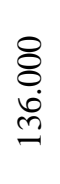 & 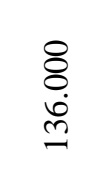 & $\begin{array}{l}8 \\
8 \\
6 \\
0 \\
-\end{array}$ \\
\hline 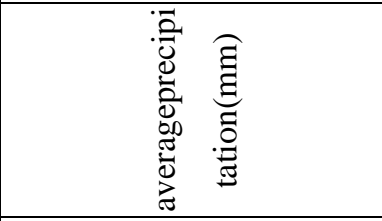 & 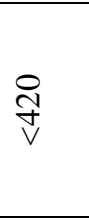 & 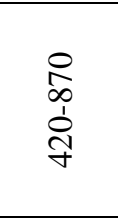 & 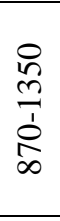 & $\begin{array}{l}\infty \\
\infty \\
\infty \\
\infty \\
\infty \\
\infty\end{array}$ & $\begin{array}{l}\stackrel{\infty}{\infty} \\
\frac{\infty}{\pi}\end{array}$ \\
\hline 总 & $\begin{array}{l}\overline{\hat{Z}} \\
\hat{0}\end{array}$ & 节 & 言 & 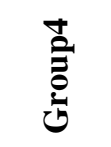 & 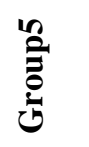 \\
\hline
\end{tabular}




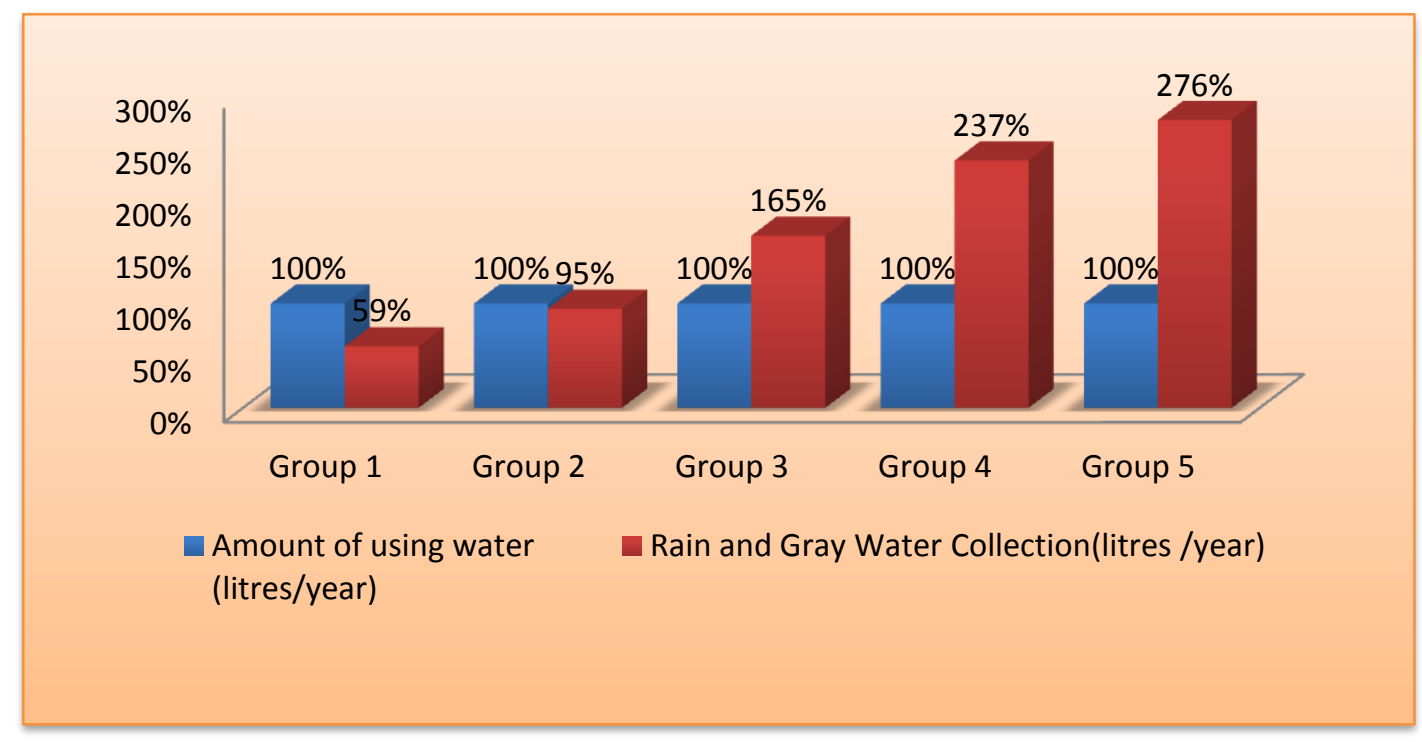

Figure 6. Comparison of gray and rain sum and need water amounts for one floor - five groups

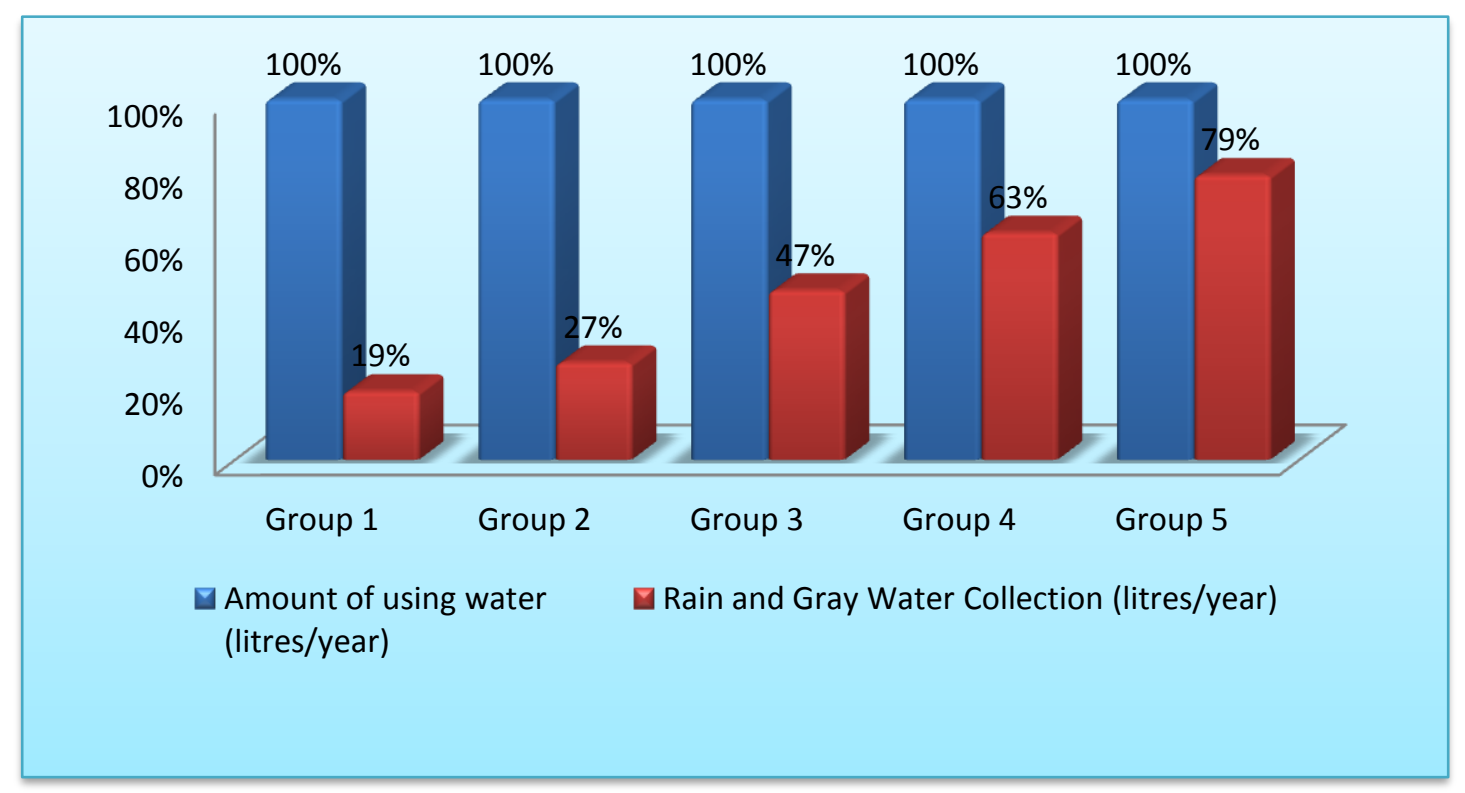

Figure 7. Comparison of gray and rain water amounts for a four floors -five groups

\section{Conclusion}

The fresh water resources are decreasing more and more in all over the world, and it is estimated that more water shortage will be experienced in the upcoming years due to certain reasons like population increase, industrial pollution, contaminating the water resources, etc. Various technologies are being developed in order to overcome these problems. One of these technologies is the collection \& utilization of rain water.

In this study, an approach was suggested with the purpose of emphasizing on the water conservation in the buildings, as well as producing a guide for the designers and users with regards to the water conservation strategies. With this purpose, 5 rain-based regions were constituted by utilizing the Köppen climate classification method. Then the ratio of meeting the needs with regards to the sample buildings both with only rain water, and also with rain water \& grey water, was calculated.

The annual water utilization needs of a family of 4 , living in a single-storey building can be met with the rain 
water and grey water on the rate of 59\% for the 1st Group regions, $95 \%$ for the 2nd group regions, and $100 \%$ for the 3rd, 4th and 5th regions, in accordance with the respective calculations. On the other hand, the annual water utilization need of a family of 4 , living in a four-storey building can be met with the rain water and grey water on the rate of $19 \%$ for the 1st Group region, and 27\%, 47\%, 63\%, $79 \%$ respectively for 2nd, 3rd, 4th and 5th Group regions.

These values show that the half or more than half of the water utilization needs in Group 3, 4 and 5 climatic zones can be met with rain water and grey water, in buildings with the same roof area, where the number of storeys is increased to 4 from 1 . These ratios represent the significant saving figures for our world, where the usable water is decreasing more and more.

\section{References}

[1] H. K. Levario, “design for water”, Paperback ISBN: 978-0-86571-580-6, 2007.

[2] UN World Water Development Report-WWDR, "Water for People, Water for Life Executive Summary", United Nations Educational, Scientific and Culturel Organization (UNESCO), UN Water, World Water AssesmentProgramme, UNESCO Publishing, ISBN: 92-3-103881-8, 2003.

[3] N. İ. Şahin, "Binalarda Su Korunumu", Yüksek LisansTezi, İstanbul Teknik Üniversitesi Fen Bilimleri Enstitüsü, İstanbul, 2010.

[4] The Caribbean Environmental Health Institute, funded by The United Nations Environment Programme (UNEP), "Rainwater Catch it While You Can", P.O. Box 30552, Nairobi, Kenya, P.O. Box 1111 The Morne, Castries, St. Lucia, 2009.

[5] G. E. Üstun. "Gri Suyun Aritmi Ve Yeniden Kullanimi”, Uludă̆ Üniversitesi Mühendislik Fakültesi Dergisi, Cilt 20, Sayı 2, 2015

[6] Rio House, "Harvesting rainwater for domestic uses: an information guide", Waterside Drive, Aztec West Almondsbury, Bristol BS32 4UD, 2018.

[7] A. Tanik, "Yağmur Suyu Toplama, Biriktirme ve Geri Kullanımı", Yüksek Lisans Tezi, İTÜ İnşaat Fakültesi, Çevre Mühendisliği Bölümü, 2017.

[8] E. Sert. "Enerji etkin kentsel peyzaj tasarımında yağmur suyu", Yüksek Lisans Tezi, İstanbul Teknik Üniversitesi Fen Bilimleri Enstitüsü, İstanbul, 2013.

[9] A. Ilhan, “Yeni Bir Su Politikasına Doğru”, Sosyal Değişim Derneği, İstanbul, 2011.

[10] F. A. Abdulla, A. W. Al-Shareef, "Roof rain water harvesting systems for household water supply in Jordan", Desalination 243, 195-207, 2008. 


\section{BIBLIOGRAPHY OF AUTHORS}

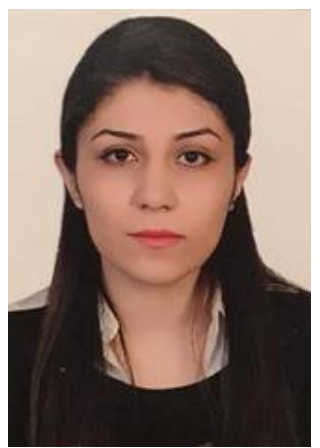

Parya Najifar obtained her BSc form Azad Islami Marageh (iran) and MSc from Gazi University Ankara, Turkey), she had been Tarasazehe Tabriz for 4 months, she wrote first paper in 2015 (The Importance of Paying Attention to Culture in Resistant Urban Development Case Study of Tabriz) (International Scientific Conference of Iranian Academicians Abroad in Turkey).

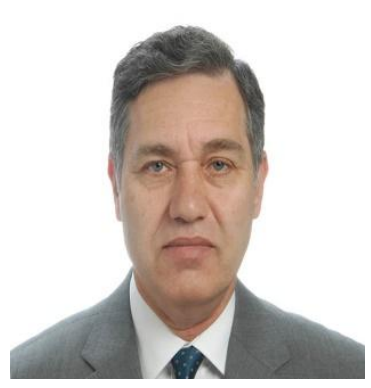

Cüneyt Kurtay (Professor Dr.) works at Gazi University, Faculty of Architecture. He has published numerous publications on renewable energy sources, sustainability and building physics. 